\title{
Certiorari through the Backdoor? \\ - the judgment by the European Court of Human Rights in \\ Burmych and Others v. Ukraine in perspective*
}

\author{
Geir Ulfstein ${ }^{*}$ and Andreas Zimmermann ${ }^{* *}$
}

In its Burmych and Others v. Ukraine judgment of October 2017 the European Court of Human

Rights has dismissed more than 12.000 applications due to the fact that given that they were not only repetitive in nature, but also mutatis mutandis identical to applications covered by a previous pilot judgment rendered against Ukraine. This raises fundamental issues as to the role of the Court within the buman rights protection system established by the ECHR, as well as those concerning the interrelationship between the Court and the Committee of Ministers.

European Court of Human Rights; Council of Europe; Committee of Ministers.

\section{A. Introduction}

In an, at least so far, largely unnoted judgment of 12 October 2017, in the case of Burmych and Others v. Ukraine ${ }^{1}$, the Grand Chamber of the European Court of Human Rights ('ECtHR') rejected more than 12.000 applications originating from Ukrainian

\footnotetext{
* This article was supported by the Research Council of Norway through its Centres of Excellence Funding Scheme, project number 223274 PluriCourts-The Legitimacy of the International Judiciary, as well as by the German Research Council (DFG) as part of the Research Group 'The International Rule of Law - Rise or Decline?'.

${ }^{*}$ Dr. juris, Professor of International Law, University of Oslo and Co-Director of PluriCourts.

${ }^{* *}$ Dr. jur, LL.M. (Harvard), Professor of International Law, University of Potsdam and Director, Potsdam Centre of Human Rights.

${ }^{1}$ Burmych and others v Ukraine, App nos 46852/13 et al., 12 October 2017 (hereafter Burmych).
} 
applicants. It did so, given that they were not only repetitive in nature, but also mutatis mutandis identical to applications covered by a so-called pilot judgment previously rendered against Ukraine. ${ }^{2}$ The ECtHR might have thereby implicitly introduced, be it only through the backdoor, and without even (explicitly) saying so, a form of certiorari into the procedural law of the European Convention on Human Rights ('ECHR'), i.e. a competence of the Court to choose the cases it wants to decide.

This judgment by the ECtHR raises the question, whether, first, the Court was indeed in a position to decide the case in the way it $\mathrm{did}^{3}{ }^{3}$ second whether this development should be welcomed as facilitating the work of the Court, ${ }^{4}$ be it only as a matter of judicial policy, and finally, third, whether the judgment should be seen as part of a larger picture in the development of the standing of the ECHR as part of the ordre public européen. ${ }^{5}$

\section{B. Background of the case}

The case concerns the prolonged non-implementation of domestic final judicial decisions in Ukraine, which, as mentioned, had already been the substance-matter of the Court's pilot judgment in the so-called Ivanov case ${ }^{6}$. Burmych forms part of more than 12.000 parallel cases, all of which had been brought before the Court since the adoption of the Ivanov judgment. In this pilot judgment, the ECtHR had found that the non-enforcement of judicial decisions in Ukraine, rendered against State entities,

\footnotetext{
${ }^{2}$ Yuriy Nikolayevich Ivanov v Ukraine, App no 40450/04, 15 October 2009 (hereafter Ivanov).

${ }^{3}$ Cf. infra C.

${ }^{4}$ Cf. infra $\mathrm{E}$.

${ }^{5}$ Cf. infra $\mathrm{F}$.

${ }^{6}$ Ivanov (n 2).
} 
as well as against State-owned and State-controlled debtors, constituted violations of both Art. 6 para. 1 ECHR and of Art. 1 Prot. 1 ECHR. ${ }^{7}$ In the Court's view, this was due to the prolonged character of such non-enforcement, as well as due to the lack of an effective domestic remedy to deal with the non-implementation. In its Ivanov judgment, the ECtHR thus ordered Ukraine to provide for an effective domestic remedy in that regard in order to secure adequate and sufficient redress for the abovementioned violations of the Convention. At the same time, it had adjourned all parallel Ivanov-type cases brought against Ukraine, and had later prolonged that period on various occasions. ${ }^{8}$

In 2012, the Court resumed its examinations of such cases with the influx of parallel cases originating in Ukraine further increasing. It is also worth noting that Ukraine has, at least so far, not adopted appropriate measures to remedy the situation; it has not done so despite having been urged to do so on various occasions by the Council of Europe's Committee of Ministers.?

By way of reaction to Ukraine's unwillingness or inability to implement the Ivanov pilot judgment, the ECtHR in 2014 again resumed its considerations of such cases, and inter alia communicated 5.000 of these cases to Ukraine in January 2015 alone. The government of Ukraine tried to cope with the matter by submitting unilateral declarations to the Court promising to pay a lump-sum amount to the respective applicant, and further undertaking to execute the underlying domestic

\footnotetext{
${ }^{7}$ Ivanov (n 2), paras. 83-84.

${ }^{8}$ Ivanov (n 2), paras. 95-101.

9 Cf. Committee of Ministers, Interim Resolutions CM/ResDH(2010)222, CM/ResDH(2011)184, $\mathrm{CM} / \operatorname{ResDH}(2012) 234$ and CM/ResDH(2017)184, Execution of the pilot judgment of the European Court of Human Rights Yuriy Nikolayevich Ivanov against Ukraine and of 386 other cases, App No 40450/04.
} 
judgment. This led the Court to strike out several thousand Ivanov-type applications from the Court's list of cases. As a matter of fact, by the time Burmych was rendered, there were more than 12.000 Ivanov-type cases pending, while the Court had already disposed of more than 14.000 such cases in the past. ${ }^{10}$

It ought to be also noted that Ukraine had previously disregarded frequent requests by the Committee of Ministers to implement the Ivanov pilot judgment and to accordingly bring its domestic legal system in line with the ECHR, as laid out by the ECtHR in the pilot judgment. ${ }^{11}$ It was this situation that led the Court's Grand Chamber, by ten votes to seven, to strike 12.143 Ivanov-type applications out of the Court's list of cases pursuant to Art. 37 para. 1 lit. c) ECHR, and, by the same token, transmit those cases to the Committee of Ministers in order for the Committee to deal with those cases as part of its efforts to implement the Ivanov pilot judgment generally. ${ }^{12}$

It ought to be noted, however, that there was a clear split within the Grand Chamber of the Court, almost all of the seven dissenting members of the Chamber (with the sole exception of the Maltese judge) being from Eastern European countries and from Turkey. This fact alone, together with the tone of the dissent, might be indicative not only of the split within the Court as such, but also as to the different perception of the Court's role as the guardian of the ordre public européen within various regions of contracting parties of the ECHR.

\footnotetext{
${ }^{10}$ European Court of Human Rights, Press Release issued by the Registrar of the Court, 12.10.2017, ECHR 307 (2017).

${ }^{11}$ For details of. paras. 146 et seq. of Burmych (n 1).

${ }^{12}$ Ivanov (n 2), operative para. 7. 


\section{Current problems facing the ECtHR}

The decision in Burmych may only be understood against the backdrop of the Court's current challenges as far as the number of applications brought before the Court, the number of currently pending applications, as well as the number of applications the Court has dealt with one way or the other, are concerned.

It is first worth noting that the annual number of applications brought before the Court, and then allocated to a judicial formation, increased continually for ten years since 2003 until it reached its peak in 2013 with 65.800 new cases per year. Until 2015 the number then decreased, albeit only somewhat, to 40.600. However, in 2016 the number rose again to $53.500 .{ }^{13}$

Thus, there has been, and continues to be, an extremely high number of applications. In particular, the number of applications submitted in 2016 shows that the decrease that occurred in 2015 may have been of a temporary nature. Yet, even the somewhat lower figure for 2015 still figured in the range of the high number of applications submitted during the years 2006-08.

At the same time, the number of applications pending before a judicial formation started decreasing earlier, from its extreme peak in 2011 (151.600 cases) to less than half of pending cases in 2015 (64.850) ${ }^{14}$ This was due not only to the decrease in the number of applications submitted, but first and foremost to the

13 Cf. European Court of Human Rights, Analysis of statistics 2016, 4 $<$ www.echr.coe.int/Documents/Stats analysis 2016 ENG.pdf> accessed 8 February 2018 (hereafter Analysis 2016). ${ }^{14}$ Cf. Analysis 2016 (n 13) 4. 
reforms introduced by Protocol $14^{15}$, improved administrative procedures, as well as to additional resources allocated to the Court. Yet, despite these reforms, the number of pending cases accumulated in 2016 to $79.750 .{ }^{16}$ This confirms that despite the various reforms undertaken, the Court was still not able to permanently decrease the number of pending cases. Rather, after a somewhat steep decline during the years $2010 / 2011-14 / 15$ the backlog started increasing once again. What is more is that the Court has been mostly able to reduce the number of the easiest cases by use of the single judge formation and hence the outstanding cases are more difficult, and thus will also take more time, to decide.

Alarmingly, out of the overall number of 79.750 cases pending as of December 31, 2016, a total number of 18.171 cases have been filed against Ukraine alone. ${ }^{17}$ Ukraine was the contracting party with the highest number of cases pending against it: $22,8 \%$ of all cases pending as of this date having been brought against Ukraine, the second being Turkey with 12.600 outstanding cases (15.8\% of all pending applications). ${ }^{18}$

What is however significantly more relevant in order to assess the current challenges for the Court, which might have significantly influenced the Court's approach in Burmych, is the ratio between communicated cases, i.e. those pending cases which have been sent to the respective government for their comments on the one hand, and actual judgments rendered on the other. The discrepancy between

\footnotetext{
15 Explanatory Report to Protocol No. 14 to the Convention for the Protection of Human Rights and Fundamental Freedoms, amending the control system of the Convention, Council of Europe Treaty Series no 194, 13 May 2004.

${ }^{16}$ Cf. Analysis 2016 (n 13) 4.

${ }^{17}$ Cf. Analysis 2016 (n 13) 12.

${ }^{18}$ Cf. Analysis 2016 (n 13) 8, Chart 3.
} 
these two figures continuously and quite significantly increased from 2,52:1 in 2013 to $4,42: 1$ in $2016,{ }^{19}$ which means that more and more cases actually wait for judicial formations to decide them.

On the whole, therefore, one can clearly see that the ECtHR continues to be overloaded with cases, the vast majority of which are of a repetitive character ${ }^{20}$. Despite hopes to the contrary, neither the Court itself nor contracting parties of the ECHR have been able to bring about a solution to this problem, at least not in a sustainable manner, by the entry into force of the Protocol 14 in 2010. Therefore, there is no doubt that there continues to be an ongoing need to improve the effectiveness of the decision-making process of cases pending at the ECtHR. By the same token this also raises the issue about possible further restrictions of admissibility. These considerations apply especially to cases against States like Ukraine that see a huge amount of cases pending against them, and represent a large part of the Court's workload.

It is also particularly relevant to note, as actually unfortunately confirmed by the Burmych judgment itself, that the Court is not only facing a lack of implementation of its 'regular' judgments, but that also some of its pilot judgments, which by their very nature are meant to address the problem of repetitive cases, are not implemented by relevant contracting parties. Ukraine being the relevant example at hand as far as the Ivanov pilot judgment is concerned. This holds true despite the fact

\footnotetext{
${ }^{19}$ Cf. Analysis 2016 (n 13) 10, Chart 8.

${ }^{20}$ Cf. Glas, Lize R., The Functioning of the pilot-judgment procedure of the European Court of Human Rights in Practice, NQHR 2016, 46
} 
that, as a matter of principle, that the pilot judgment approach, as developed by the Court, may be considered a success. Yet, the Committee of Ministers has not been able to force those reluctant contracting parties to (fully) implement pilot judgments rendered against them to change their attitude, the Ivanov pilot judgment rendered against Ukraine again being a prominent example.

It is this overall background that lead the ECtHR to a limine reject the more than 12.000 Ivanov-type applications in Burmych in an obvious attempt to reduce its own case load. All these more than 12.000 Ivanov-type cases are now waiting for the Committee of Ministers to fulfill its own obligations under the ECHR when it comes to the enforcement of the Court's judgments. The Court's judgment in Burmych might thus be interpreted as an attempt, by the Court, to have the Committee of Ministers strengthen its enforcement vis-à-vis Ukraine in the Ivanov case, and even more generally when it comes to the implementation of pilot judgments by contracting parties of the ECHR.

However, in doing so, the Court by the same token might have also introduced, and be it only implicitly, in substance some form of certiorari into the Convention system, a procedure the contracting parties so far continuously have rejected to adopt.

\section{Concept of certiorari and the ECtHR}

In the past, several proposals have been brought forward aiming at reducing the workload of the Court, and increasing its ability to cope with the continuously 
high number of applications, including repetitive cases. Among others, there has been, time and again, a debate as to whether the Court should be enabled to more or less freely select the cases it wants to decide, and thereby, by way of a formal treaty amendment, introducing a certiorari procedure, known in some domestic systems, and especially in the United States. Not the least two former Presidents of the Court, i.e. Rudolf Bernhardt and Luzius Wildhaber, are among the proponents for a competence of the Court to select its cases. ${ }^{21}$

This debate as to whether or not to introduce the concept of certoriari into the ECHR was (still) ongoing while Protocol 14 was being negotiated. In that regard, it is worth noting that Protocol 14 introduced, among some other new procedures, in the newly drafted Art. 27 para. 1 ECHR the possibility for a single judge to declare inadmissible or strike out cases "where such a decision can be taken without further examination" 22 . Besides, a committee of three judges was endowed with the same power, but also, under Art. 28 para. 1 lit. a) and b) ECHR, with the competence to render a judgment on the merits if the relevant question raised by the application was already the subject of "well-established case-law" of the Court ${ }^{23}$. At the same time, however, as confirmed by the Explanatory Report accompanying Protocol 14 forming part of the travaux préparatoires of the amending protocol, a proposal "that the Court should be given discretion to decide whether or not to take up a case for

\footnotetext{
${ }^{21}$ Rudolf Bernhardt in Ulrike Deutsch and Rüdiger Wolfrum (eds.), The European Court of Human Rights Overwhelmed by Applications: Problems and Possible Solutions (Springer 2009), 29; Steven Greer and Luzius Wildhaber, 'Revisiting the Debate About 'Constitutionalizing' the European Court of Human Rights', (2012) 12 Human Rights Law Review 4, 655, at 685-686.

${ }^{22}$ Explanatory Report to Protocol No. 14 to the Convention for the Protection of Human Rights and Fundamental Freedoms, amending the control system of the Convention, Council of Europe Treaty Series no 194, 13 May 2004 , para. 67.

${ }^{23}$ Ibid., para. 68.
} 
examination (system comparable to the certiorari procedure of the United States Supreme Court)" ${ }^{24}$ was rejected. The underlying reason was that the contracting parties of the ECHR, simultaneously being the negotiating States of the Protocol 14 "felt that the principle according to which anyone had the right to apply to the Court should be firmly upheld." ${ }^{25}$ Any indication that the Court might have such power of rejection was thus not included in the text of the ECHR, as amended.

This proposal was also unequivocally rejected in the 2006 Report of the Wise Persons to the Committee of Ministers, which had been mandated to analyze the long-term effectiveness of the ECHR control mechanism, including the initial effects of Protocol No. 14 and the other decisions previously taken in May 2004, ${ }^{26}$ as running counter to the very concept underpinning the Convention system. As its report put it:

"[The Group] felt that a power of this kind would be alien to the philosophy of the European human rights protection system. The right of individual application is a key component of the control mechanism of the Convention and the introduction of a mechanism based on the certiorari procedure would call it into question and thus undermine the philosophy underlying the Convention. Furthermore, a greater margin of appreciation would entail a risk of politicizing the system as the Court would have to select cases for

\footnotetext{
${ }^{24}$ Ibid., para. 34.

25 Ibid., para. 34.

${ }^{26}$ Report of the Group of Wise Persons to the Committee of Ministers, CM (2006) 203, 15 November 2006.
} 
examination. The choices made might lead to inconsistencies and might even be considered arbitrary."27

What is more is that the contracting parties of the ECHR in their 2010 Interlaken Declaration, adopted by the 'High Level Conference on the Future of the European Court of Human Rights ${ }^{28}$, while not even mentioning the concept of certiorari, had instead formally “(...) [r]eaffirm[ed] the commitment of the States Parties to the Convention to the right of individual petition $(\ldots) " .{ }^{29}$

In the same vein, the ECHR's contracting parties' 2011 Izmir Declaration ${ }^{30}$ again "(...) [r] eaffirm[ed] the attachment of the States Parties to the right of individual petition as a cornerstone of the Convention mechanism (..." ${ }^{\prime 31}$, and merely considered appropriate measures to dissuade 'clearly inadmissible applications', while the concept of certiorari by its very nature also entails the rejection of applications which might be well-founded as far as their admissibility and their merits are concerned. This approach was then mutatis mutandis reiterated in their 2012 Brighton Declaration ${ }^{32}$, as well as in the 2015 Brussels Declaration, the latter being

\footnotetext{
27 Ibid., para. 42.

28 Cf. High Level Conference on the Future of the European Court of Human Rights, 19 February 2010 <www.echr.coe.int/Documents/2010_Interlaken_FinalDeclaration_ENG.pdf> accessed 8 February 2018.

${ }^{29}$ Ibid., operative para. 1.

30 Cf. High Level Conference on the Future of the European Court of Human Rights, 26-27 April 2011

<www.echr.coe.int/Documents/2011_Izmir_FinalDeclaration_ENG.pdf> accessed 8 February 2018.

31 Ibid., operative para. 1.

32 Cf. High Level Conference on the Future of the European Court of Human Rights, 19-20 April 2012 <www.echr.coe.int/Documents/2012_Brighton_FinalDeclaration_ENG.pdf> accessed 8 February 2018, in particular, operative para. 13.
} 
the result of the "High-level Conference on the 'Implementation of the European Convention on Human Rights, our shared responsibility"'. 33

Nor indeed was such a competence to exercise the right of certiorari, to say the least, among the favoured options by the Council of Europe's Steering Committee for Human Rights $(\mathrm{CDDH})$ representing the contracting parties of the ECHR. In was once again stated by the CDDH in 2016, making explicit reference to the certiorari procedure:

“The willingness to explore the alternative models was not only weakened by the recent positive results achieved by the Court in addressing its caseload but also by its ability to reconcile the obligation of judicial adjudication with the role of identifying systemic problems in line with the Committee of Ministers Resolution (2004) 3 on judgments revealing an underlying systemic problem. Reference was also made to the need to preserve a system based on the equal treatment of applicants and to avoid the risk of a discretionary assessment suggesting a perceived lack of legitimacy, possibly leading to a weakening of trust in the Convention system. In that respect, the effects of the discretionary certiorari authority of the US Supreme Court were put forward, the main risk being the appearance of a court that is politically motivated in its case selection, raising questions as to the democratic legitimacy of judicial review." 34

\footnotetext{
33 Cf. High-level Conference on the "Implementation of the European Convention on Human Rights, our shared responsibility”, 27 March 2015 <www.echr.coe.int/Documents/Brussels_Declaration_ENG.pdf> accessed 8 February 2018, operative para. 1.

${ }^{34}$ Report of the Steering Committee for Human Rights (CDDH), Council of Europe, The longer-term future of the system of the European Convention on Human Rights, 2016, para. 91 (footnotes omitted).
} 
However, it is worth noting that the $\mathrm{CDDH}$ in 2016 found that there had been a positive development in the Court's capacity to deal with repetitive cases. This stands in line with the statistics outlined above, where indeed until 2015 the respective number has developed in such a manner. Such an optimistic view may no longer be well-founded, however, as again confirmed by the above numbers showing a renewed significant increase, as of 31 December 2016, in the number of pending applications. There is also reason to repeat that the Court, in accordance with Art. 35 para. 2 lit. a) and b) ECHR, already possesses several possibilities to deny access for certain cases, also based on more subjective assessments, such as whether a given case is 'manifestly ill-founded', or whether the applicant has not suffered a 'significant disadvantage'.

Furthermore, it is worth noting that already under the current system not all admissible cases are treated similarly. Rather, the Court prioritizes cases, ${ }^{35}$ and it can under appropriate circumstances use the pilot judgment procedure. ${ }^{36}$ Finally, negative certiorari, i.e. dismissing groups of cases rather than positively selecting individual cases to be reviewed, involves much less discretion, i.e. power, to the Court, an aspect that is illustrated specifically by the Burmych case.

It is in light of this approach, by the contracting parties of the ECHR, to reject the concept of certiorari when it comes to applications brought before the ECtHR,

\footnotetext{
35 Cf. European Court of Human Rights, The Court's Priority Policy <www.echr.coe.int/Documents/Priority_policy_ENG.pdf> accessed 8 February 2018.

${ }^{36}$ Cf. European Court of Human Rights, The Pilot-Judgment Procedure, Information note issued by the Registrar <www.echr.coe.int/Documents/Pilot_judgment_procedure_ENG.pdf> accessed 8 February 2018.
} 
one has to now evaluate whether the approach chosen by the Court in Burmych, as at least coming close to such a system, is indeed compatible with the system of human rights protection set up by the ECHR.

\section{E. Compatibility of the Court's approach in Burmych with the ECHR}

The Court's judgment in Burmych is based on a systemic approach to the respective functions of the contracting parties, the ECtHR and the Committee of Ministers in a situation where a member State fails to implement a pilot judgment. The Court therefore discusses Art. 1 ECHR, i.e. the contracting parties' obligations to respect human rights; it furthermore relies on Art. 19 ECHR generally providing for the establishment of the Court in order to " $[t]$ o ensure the observance of the engagements undertaken by the High Contracting Parties in the Convention and the Protocols thereto"; and, finally, on Art. 46 ECHR providing for the specific role of the Committee of Ministers to supervise the implementation of the Court's judgments. This establishes the background for the use of Art. 37 para. 1 lit. c) ECHR empowering the Court to, under certain circumstances, strike an application out of its list of pending cases. It is those various arguments brought forward by the Court that will now be scrutinized.

\section{Art. $1 \mathrm{ECHR}$ and the obligations of the contracting parties}

The majority opinion in Burmych argues that providing redress for the nonenforcement or the delayed enforcement of domestic judgments in situations where 
the Court has previously rendered a pilot judgment on the matter "is not compatible with the subsidiary role which the Court is supposed to play in relation to the High Contracting Parties under Article 1". ${ }^{37}$ The majority observes that "it runs the risk of operating as part of the Ukrainian legal enforcement system and substituting itself for the Ukrainian authorities in directing 'appropriate and sufficient redress for the non-enforcement or delayed enforcement of domestic decisions"'. ${ }^{38}$

One might question whether this reliance on Art. 1 ECHR may indeed serve as a valid legal basis for the conclusion drawn by the Court. It is obviously true, as implied by the Court in this statement, that Art. 1 ECHR enshrines the fundamental obligation of the ECHR's contracting parties to uphold and abide by the human rights guarantees, as contained in the Convention. It that sense the role of the Court is indeed merely of a subsidiary or complimentary character.

It may however also be argued that the majority disregards the system of dispute settlement underlying the ECHR as introduced by Protocol 11 as strongly contended by the minority. ${ }^{39}$ Ever since the Convention provides for the Court's compulsory (rather than until then optional) jurisdiction, and has brought about the right of individuals to bring applications before the Court in situations where Art. 1 ECHR is being violated. This in turn presupposes by its very nature, and as least as a matter of principle, that should the parties to the Convention fail to fulfill their respective obligations under Art. 1 ECHR, it is then for the Court to, as Art. 19

\footnotetext{
${ }^{37}$ Burmych (n 1), para. 155.

${ }^{38}$ Ibid., para. 155.

${ }^{39}$ Ibid., Joint Dissenting Opinion Of Judges Yudkivska, Sajó, Bianku, Karakaş, De Gaetano, Laffranque and Motoc (hereafter Joint Dissenting Opinion), para. 15.
} 
ECHR puts it, "ensure the observance of the engagements undertaken by the High Contracting Parties in the Convention and the Protocols". By however striking out the repetitive, yet still clearly meritorious, more than 12.000 Ivanov-type applications, the Court itself is no longer fulfilling this task arising under Art. 19 ECHR, and hence leaves those applicants at the mercy of the party (i.e. in the case at hand Ukraine) that has been (for whatever reason) for a long time clearly and systematically not fulfilling its obligations under Art. 1 ECHR.

On the other hand, the fact that Ukraine does not follow up the Ivanov pilot judgment may be perceived not only as a violation of Art. 1 ECHR, but also as a systemic failure in the institutional relationship between a contracting State and the Court. The function of the Court is based on a loyal implementation of its judgments by member States. If this premise is consistently not fulfilled in essential matters, it may be argued that it should have consequences for the role of the Court and/or the Committee of Ministers.

\section{Art. 19 ECHR and the judicial function of the Court}

Art. 19 ECHR tasks the Court to "ensure the observance of the engagements undertaken by the High Contracting parties" in the Convention and its various protocols. Yet, the Court finds in its judgment ${ }^{40}$, somewhat surprisingly, that by striking out the 12.000 Ivanov-type cases the Court is just doing this, namely to ensure

${ }^{40}$ Ibid., paras. 178-181, in particular para. 181. 
the observation of ECHR-based obligations by Ukraine. One wonders whether this will really induce Ukraine to do so, or whether instead Ukraine (and other contracting parties who find themselves in a similar situation) might not rather use the Court's approach as an excuse to even further delay the implementation of the Ivanov pilot judgment.

This brings us to the functions of the Court as a judicial organ. The majority states:

"At the beart of the present applications lies the division of competence established by the Convention between, on the one hand, the Court, whose function is to "ensure the observance of the engagements undertaken by the High Contracting Parties in the Convention and the Protocols thereto" (Article 19 of the Convention) and, on the other, the Committee of Ministers "which shall supervise [the] execution" of the final judgments of the Court (Article 46 of the Convention). The understanding of that division of responsibility has evolved in the light of the Court's case-law as it has developed with regard to changing circumstances, and notably the proliferation of structural and systemic violations of the Convention." ${ }^{41}$

The wording of Art. 19 ECHR implies that the Court is an enforcement organ ('ensure the observance'). But it must be emphasized that the Court is a judicial organ

\footnotetext{
${ }^{41}$ Ibid., para. 141 (emphasis added).
} 
with an 'enforcement function' only to the extent that its judgments are legally binding upon the respondent State and thereby exercise pressure on the contracting States to fulfill their legal obligation to implement the Court's judgments. At the same time, however, the ECHR gives competence to the Committee of Ministers, as the executive organ, to supervise such implementation.

The Court further argues that Art. 19 ECHR was not meant to "provide individualised financial relief in each and every repetitive case". ${ }^{42}$ Against the majority's view, the Court's minority emphasizes the importance of individuals' access to the Court. ${ }^{43}$ The minority argues that the claims contained in the 12.143 applications joined to the applications in this case had not 'been the subject of a judicial determination as to the facts or legal qualification'. ${ }^{44}$ Also, the 'absorption of rights of some into the rights of others' is seen as 'a major threat to the idea of individual fundamental human rights'. ${ }^{45}$ Thousands of applications and potential violations would wait in a 'legal limbo'. Some of these cases represent 'vital interests'. Mention is made of the fact that three of the five applicants are victims of the Chernobyl disaster. ${ }^{46}$ Furthermore, the minority criticizes the judgment for acknowledging future applicants in such cases as 'victims', without even examining these cases. ${ }^{47}$

\footnotetext{
42 Ibid., para. 181.

43 Ibid., Joint Dissenting Opinion, para. 8.

${ }_{44}^{4}$ Ibid., Joint Dissenting Opinion, para. 3.

45 Ibid., Joint Dissenting Opinion, para. 26.

${ }^{46}$ Ibid., Joint Dissenting Opinion, para. 30.

${ }^{47}$ Ibid., Joint Dissenting Opinion, para. 6.
} 
It can also be argued that the Court sets aside its role under Art. 41 ECHR which, the Court claims, is only accessory to the Court's role under Art. 19 ECHR. ${ }^{48}$ Hence, the enforcement of international judicial decisions would constitute the very litmus test for any international dispute settlement mechanism. Put otherwise: what is a judgment of an international body worth without an effective remedy for the violation of international law previously having been determined by the respective international judicial body? Accordingly, what the Court is doing is to de facto replace for all Ivanov-type applicants their right arising under Art. 41 ECHR to request, and eventually be granted, financial compensation for the violation of their rights guaranteed by the ECHR and its protocols by the mere possibility that the Committee of Ministers might induce the violating State (i.e. in the case at hand Ukraine) to implement the Ivanov pilot judgment ad futurum, and in doing so eventually will also provide financial compensation as to past cases. One might wonder, whether indeed this constitutes a fulfillment, by the Court, of its obligation to ensure that the rights guaranteed by the Convention are being observed, which rights, as the Court has stated time and again are meant to be "practical and effective, not theoretical and illusory" ${ }^{\prime 4}$.

On the other hand, the Court held that the legal issues concerning nonenforcement of domestic decisions in Ukraine were already resolved in the Ivanov

\footnotetext{
${ }^{48}$ Burmych (n 1), para. 181.

${ }^{49}$ Cf. inter alia Airey v Ireland, App no 6289/73, 9 October 1979, para. 24 with further references; Beer and Regan $v$ Germany, App no 28934/95, 18 February 1999, para. 57; Kutic v Croatia, App no 48778/99, 1 March 2002, para. 25; Weissman and Others v Romania, App no 63945/00, 4 May 2006, para. 37; Christian Democratic People's Party v Moldova (no 2), App no 25196/04, para. 25 (mutatis mutandis), 2 February 2010; Peretyaka and Sheremetyev v Ukraine, App nos 17160/06 and 35548/06, para. 40 (mutatis mutandis), 21 December 2010.
} 
pilot judgment. The problems are now seen by the Court as fundamentally of a 'financial and political nature' and can only be resolved by the respondent State and the Committee of Ministers. ${ }^{50}$ The Court concluded that 'no useful purpose is served' if it continued to deal with this cases. ${ }^{51}$

\section{Art. 46 ECHR in the context of pilot judgments and the supervisory role of the Committee of Ministers}

It is almost a truism that the introduction of the concept of pilot judgments into the jurisprudence of the ECtHR constituted a milestone in the Court's efforts to streamline the Court's proceedings and to, at the same time, tackle the issue of repetitive cases originating in one contracting party hindering the Court to deal with applications that raise new issues under the Convention, and eventually even involve significantly more serious violations of the Convention. It is therefore for good reason that the ECHR's contracting parties have, time and again, confirmed the compatibility of the Court's general approach on the matter with the Convention. ${ }^{52}$

It is also obviously true that, once the contracting parties have accepted the pilot judgment concept, it is then for the Committee of Ministers to see about that

\footnotetext{
${ }^{50}$ Ibid, para. 195. See also para. 197.

51 Ibid., para. 199.

${ }^{52}$ High Level Conference on the Future of the European Court of Human Rights, 19-20 April 2012, operative para. 20 c) <www.echr.coe.int/Documents/2012_Brighton_FinalDeclaration_ENG.pdf> accessed 8 February 2018.
} 
such pilot judgments are being implemented by the respective contracting party, even subject to the Committee's 'enhanced procedure'. 53

What is however special in the Court's approach in Burmych is that it deals with a situation where the State concerned has not taken concrete steps (yet) to implement the pilot judgment in question, and where both the Court, as well as the Committee of Ministers, had tried in vain for years to bring about a change in the situation resulting in an ever increasing number of identical postpilot judgment applications. As a matter of fact, the Court decided that the relevant applications should be struck out of the list, rather than being adjourned as in a pilot judgment.

An argument in favor of striking out these cases would be that the more than 12.000 applicants, the applications of whom have been taken off the Court's list of pending cases, are not worse off, as compared to a situation where their respective cases would have been decided by the Court, and where the Committee of Ministers would have then been responsible to take care of the enforcement of these individual judgments. Such argument, however, would only hold true provided as part of the execution of the Ivanov pilot judgment, those applicants would be granted individual compensation in line with the standards developed within the framework of Art. 41

\section{ECHR.}

But the comparison should not only be with individualized judgments by the Court, but with cases forming part of pilot judgments. The Court has in the Burmych

\footnotetext{
${ }^{53}$ Ibid., operative para. 27. See as to the enhanced procedure: Supervision of the execution of judgments of the European Court of Human Rights: procedure and working methods for the Committee of Ministers' Human Rights meetings, paragraph 8 (a) (https://search.coe.int/cm/Pages/result details.aspx?ObjectId=09000016806303a9, accessed 13 February 2018
} 
case decided that the over 12.000 cases - despite stricken out - shall be dealt by the Committee of Ministers 'within the framework of the general measures of execution of the above-mentioned Ivanov pilot judgment, including the provision of redress for the non-enforcement or delayed enforcement of domestic decisions, as stipulated in the fifth operative provision of that judgment, and payment of the judgment debt'. ${ }^{54}$

This means that these cases should be dealt with by the Committee of Ministers in the same way as the cases covered by the Ivanov pilot judgment. The difference from a pilot judgment is that the Court no longer can be involved in the execution of this judgment. On the other hand, the Court states that its decision to strike out the application is without prejudice to its power to restore the applications and any future application that have been stricken out to the list of cases, and that it may be appropriate to reassess the situation within two years of the delivery of the Burmych judgment. ${ }^{55}$

Although the Court has required that the cases stricken out in Burmych should receive no disadvantageous treatment compared to the cases covered by the Ivanov judgment, it is less than clear, whether the Committee of Ministers might not accept a general compensation scheme which will not be equivalent to the compensation the applicants could have expected had their cased not been dismissed by the Court by way of Burmych. In that regard, it remains to be seen whether both, the respondent State, as well as the Committee of Ministers, in the Burmych cases will necessarily consider that only the amount of compensation required under Art. 41 ECHR in

\footnotetext{
${ }^{54}$ Burmych (n 1), operative para. 4.

55 Ibid., para. 223.
} 
case individual judgments were to be enforced also amounts to "adequate and sufficient redress" as required under the fifth operative provision of the Ivanov pilot judgment. ${ }^{56}$

\section{Art. 37 para. 1 lit. c) ECHR and the Court's discretion to strike applications from its list of cases}

Finally, the Court relies on Art. 37 para. 1 lit. c) ECHR in order to justify the striking out of the repetitive Ivanov-type applications. It ought to be first mentioned that the wording of this provision provides the Court with a broad discretion since it may "decide to strike an application out of its list of cases where the circumstances lead to the conclusion that (...) for any other reason established by the Court, it is no longer justified to continue the examination of the application. ${ }^{.57}$ Hence, for one, there is no need to establish that it is indeed no longer justified to continue the examination of a given application. Rather, it suffices that the Court finds that circumstances exist which lead to such conclusion. This already introduces a significant subjective element into the text of the provision. Besides, and even more obvious, the Court may determine any other reason apart from those mentioned in Art. 37 para. 1 lit. a) and b) ECHR in order to strike an application out of the Court's list of cases. ${ }^{58}$ This is even further stressed in the equally authentic French text of the Convention which

\footnotetext{
${ }^{57}$ Emphasis added.

58 Art. 37 para. 1 lit. c) ECHR.
} 
refers to "tout autre motif dont la Cour constate l'existence", i.e. any other ground or motive.

At the same time, however, a systemic interpretation of the provision seems to indicate that all three alternatives of Art. 37 para. 1 ECHR have in mind a situation where the claim has become moot, one way or the other, and where for that reason the applicant does not have any legally protected interest (anymore) to have his or her case be still decided by the Court. Yet, this does not seem to be the situation of the applications covered by the Burmych judgment where not only the rights of the applicants under the Convention have been violated, but where they have also bona fide tried to have such rights vindicated first by way of domestic procedures, and then later before the ECHR.

It ought to be also noted that the said provision, which had already become part of the Convention in 1985 by way of Protocol 8, was never meant to be broadly interpreted. Rather, as the then official explanatory report put it, "the scope of this sub-paragraph [i.e. the current Art. 37 para. 1 lit. c) ECHR] should be limited to cases which are comparable to those mentioned in sub-paragraphs a) and b), for example where the applicant has died and his heirs do not have a sufficient legal interest to justify the further examination of the petition on their behalf." 59

Given this background, and notwithstanding the limited normative relevance of these travaux préparatoires, one might wonder whether the reliance, by the Court,

\footnotetext{
${ }^{59}$ Explanatory Report to the Protocol No. 8 to the Convention for the Protection of Human Rights and Fundamental Freedoms, Council of Europe Treaty Series no 118, 19 March 1985, para. 35 <https://rm.coe.int/16800c96fe> accessed 8 February 2018.
} 
on the said provision was warranted. If that were correct, it could be argued that Art. 37 para. 1 lit. c) ECHR would grant the Court an almost unfettered discretion to strike cases out and could thus arguably amount to some sort of a certiorari procedure. Yet, as shown, the contracting parties of the ECHR have, time and again, rejected the proposition to endow the Court with such a power.

On the other hand, the relationship between the Court and the Committee of Ministers has been subject to a dynamic and flexible development, illustrated not the least by the introduction of the pilot judgment procedure. The Burmych judgment moves this a step further in a situation where a pilot judgment has proved to be without effect. The use of Art. 37 para. 1 lit. c) ECHR might thus be consistent at least with the overall purpose in ensuring a meaningful functional relationship between the roles of the Court and that of the Committee of Ministers.

In its dissent the minority opinion also brought forward procedural arguments. It argued that neither the parties to the case, nor indeed the Committee of Ministers, were informed, much less consulted, about the possible outcome of the case ${ }^{60}$ and that the outcome in Burmych thus came as a surprise to both of them. It ought to be noted, however, as the majority mentions, that the Court had previously indicated the need to redefine 'its role in circumstances where the respondent State has failed to take general remedial measures within a reasonable time and the consequences that should be drawn from this in the light of Article 46 of the Convention'. ${ }^{61}$

\footnotetext{
${ }^{60}$ Burmych (n 1), Joint Dissenting Opinion, para. 11.

${ }^{61}$ Ibid., para. 182; E.G. v. Poland and 175 Other Bug River, App no 50425/99, 23 September 2008, para. 27.
} 
Finally, the minority opinion argued that the Court, instead of striking out the 12.000 Burmych-type applications, could have used two other alternatives, explicitly recognized by the Protocol 14. For one, it could have applied Article 28 para. 1 lit. b) ECHR allowing committees of three judges to render judgments on the merits in cases involving well-established case law of the Court. ${ }^{62}$ Or, in the alternative, the Committee of Ministers could have brought infringement procedures against Ukraine pursuant to Article 46 para. 4 ECHR. ${ }^{63}$

While the first alternative would have meant that fewer resources are spent, it would still mean that judicial capacity is used with little prospects of making any real difference for the respective applicants. The second option in turn had not yet been used ever at the time the Burmych case was decided, given that the current infringement procedure brought by the Committee of Ministers against Azerbaijan was only lodged in December $2017 .{ }^{64}$ Besides, the usefulness of starting an infringement procedure against Ukraine for not implementing the Burmych type of cases may be questioned anyhow since the underlying problems continue 'owing to the size of the debt accumulated during previous years and the limited funding allocated for the purposes of full enforcement of outstanding judgments' ${ }^{35}$

\footnotetext{
${ }^{62}$ Ibid., Joint Dissenting Opinion, para. 24.

63 Ibid., Joint Dissenting Opinion, para. 20.

${ }^{64}$ Cf. Committee of Ministers, Interim Resolution CM/ResDH(2017)429 Execution of the judgment of the European Court of Human Rights Ilgar Mammadov v Azerbaijan, App No 15172/13, 7 December 2017 <https://rm.coe.int/168076f1fd> accessed 8 February 2018.

${ }^{65}$ Burmych (n 1), para. 131.
} 


\section{F. Burmych and Others v. Ukraine in perspective}

What are then the implications and the possible consequences of Burmych for the protection of human rights in Europe, and for the overall legitimacy of the Court? The minority is clearly right that striking the cases out of the Court's list of cases and leaving them to the Committee of Ministers means that they are not dealt with individually by the Court. It will be up to the Committee of Ministers how to supervise national implementation, taking into account that the Court requires that the cases shall 'be dealt with in the framework of the general measures of execution of the above-mentioned Ivanov pilot judgment, including the provision of redress for the non-enforcement or delayed enforcement of domestic decisions ${ }^{366}$. It is also true that this may even deter future victims from submitting their cases to the Court at the first place.

However, the proceedings in the Court over the years have been of little avail to the applicants anyhow. Rather, the structural problem remains, and the Court's judgments and decisions have so far not lead to the fulfillment of the applicants' rights. As the majority of the Court put it, 'nothing will be gained, nor will justice be served by the repetition of its findings in a lengthy series of comparable cases, which would place a significant burden on its own resources, with a consequent impact on its considerable caseload' nor would 'such as exercise (...) contribute usefully or in any meaningful way to the strengthening of human rights protection under the Convention'. ${ }^{67}$ At the same time, however, as the minority argued, the majority

\footnotetext{
${ }^{66}$ Ibid., operative para. 4.

${ }^{67}$ Ibid., para. 174.
} 
decision 'does not mean that the human rights situation in Europe is any better' either. $^{68}$

Striking out over 12.000 applications, and the signal it represents to the 120.000 non-executed domestic judgment holders, obviously means that the Court will have more capacity to deal with urgent cases and cases posing significant judicial issues, possibly with precedential effects, and may make a real difference for the applicants provided there will be a good faith implementation by the respondent State. On the whole fewer cases might also contribute to improved quality and consistency of the Court's jurisprudence.

But to what extent can, and possibly should, we expect the Court to apply the Burmych approach in other situations? Burmych was handed down after Ukraine's nonimplementation by the former Ivanov pilot judgment. Pilot judgments have been used also in other instances. Yet, it seems that '[m]ost pilot judgments have been successfully implemented by means of general remedial measures introduced by the respondent States ${ }^{36}$ which fact restricts the number of situations where reliance on the Burmych approach would be appropriate.

However, the Court could consider applying pilot judgments more extensively, as a basis for a subsequent Burmych judgment. This may be of particular relevance for member States that have the largest number of pending cases. Altogether, six countries represent $74,9 \%$ of the Court's caseload, in other words

\footnotetext{
${ }^{68}$ Ibid., Joint Dissenting Opinion, para. 39.

69 Ibid., para. 163. Cf. European Court of Human Rights Factsheet Pilot Judgments, November 2017 $<$ http://www.echr.coe.int/Documents/FS_Pilot_judgments_ENG.pdf> accessed 8 February 2018.
} 
three fourths of the pending cases. ${ }^{70}$ A future combination of pilot and Burmych judgments could possibly improve the Court's case load significantly, even if it was used only as the last resort. A more extensive use of the Burmych approach would however raise significant legal, as well as political challenges for the overall Convention system.

First, it would raise procedural issues. If the Court were to consider following the Burmych approach in future cases, it would seem that the parties should have the possibility to express their views on such an outcome. This in turn would again make the procedure much more cumbersome.

As a matter of judicial policy, this might also involve an increased, possibly even permanent, East-West divide among the judges in possible future Burmych cases although non-implementation of pilot judgments may also occur in Western European States.

Finally, there is also a need to consider whether an expansion of Burmych to other situations should be seen as being within the Court's remit, or whether it would need the consent by the Committee of Ministers, or even should be based on an amendment of the Convention. As is well-known, the introduction of pilot judgments itself was done not by way of an amendment, but rather by approval by the Committee of Ministers before it was applied by the Court, and was subsequently confirmed by the Brighton Declaration. ${ }^{71}$ Yet, the approach underlying the Burmych

\footnotetext{
${ }^{70}$ European Court of Human Rights, Analysis of statistics 2017, 8: Hungary (6,3 \%), Romania (17,6 \%), Turkey (13,3 $\%)$ Russia (13,8 \%) and Italy (8,3 \%). Ukraine counts for $12,6 \quad \%$ <www.echr.coe.int/Documents/Stats_analysis_2017_ENG.pdf> accessed 8 February 2018.

${ }^{71}$ High Level Conference on the Future of the European Court of Human Rights, 19-20 April 2012, operative para. 20 c) <www.echr.coe.int/Documents/2012_Brighton_FinalDeclaration_ENG.pdf> accessed 8 February 2018.
} 
judgment is more dramatic given that similar cases are not only put on hold until the deadline set by the Court for the adoption of general measures and redress as in pilot judgments; rather the cases are struck out from the Court's list. If this approach were to be indeed used on a regular basis, i.e. if 'negative certiorar' were to become a regular feature of the Court, it could be argued that it should be based on a formal amendment of the Convention, similar to Article 28 para. 1 lit. b) providing for the possibility for committees to render judgments when it comes to well-established case law.

Yet, one might also envisage a somewhat more 'organic' process. If the Committee of Ministers indeed accepts the task delegated to it by the Court in Burmych, this could be seen as tacit consent by contracting parties of the ECHR that the Court is entitled to such an approach in special circumstances. The Court could exploit such approval by applying Burmych step-by-step to possible other situations where it has repeatedly tried to obtain a change to a domestic structural problem, but without success. This could mean that, over time and through its practice, the Court would indeed develop a general negative certiorari doctrine - even if the concept of certiorari had started entering the ECHR system via the backdoor. 